\title{
PERAN PERSEPSI KETERLIBATAN ORANGTUA DAN STRATEGI PENGASUHAN TERHADAP PARENTING SELF-EFFICACY
}

\author{
Stephanie Yuanita Indrasari* \& Laily Affiani \\ Fakultas Psikologi, Universitas Indonesia, Depok \\ *Email: stephanie.yuanita@ui.ac.id
}

\begin{abstract}
Abstrak
Pada anak usia kanak-kanak madya anak mengalami perubahan di beberapa aspek kehidupannya. Hal tersebut menjadi tantangan tersendiri bagi orangtua untuk menjalankan proses pengasuhan yang positif. Pengasuhan yang dilakukan orangtua terhadap anak akan memengaruhi perilaku anak. Penelitian ini bertujuan untuk melihat pengaruh persepsi keterlibatan orangtua (ayah dan ibu) dan strategi pengasuhan secara bersamasama terhadap parenting self-efficacy. Pengukuran persepsi keterlibatan orangtua menggunakan alat ukur Reported Father Involvement Scales (Finley \& Schwartz, 2004) dan Reported Mother Involvement Scales (Finley, Mira, \& Schwartz, 2008), sedangkan pengukuran strategi pengasuhan menggunakan alat ukur Parenting Strategies Questionnaire (Laforce, 2004). Pengukuran parenting self-efficacy menggunakan alat ukur Self-Efficacy for Parenting Task Index (Coleman \& Karraker, 2000). Partisipan dalam penelitian ini adalah 270 orangtua (ayah atau ibu, boleh tidak berpasangan) yang berusia pada rentang 25-45 tahun dan memiliki anak yang usianya kanak-kanak madya (5-12 tahun). Hasil penelitian menunjukkan adanya pengaruh persepsi keterlibatan ayah dan strategi pengasuhan secara bersama-sama secara signifikan terhadap parenting selfefficacy $F(2,267)=13,805, p<0,01$. Hasil penelitian menunjukkan adanya pengaruh persepsi keterlibatan ibu dan strategi pengasuhan secara bersama-sama secara signifikan terhadap parenting self-efficacy $F(2,267)=11,021, p<0,01$. Pada penelitian ini parenting self-efficacy dapat diprediksi oleh persepsi keterlibatan orangtua di masa lalu dan strategi pengasuhan.
\end{abstract}

Kata kunci: persepsi keterlibatan orangtua; strategi pengasuhan; parenting self-efficacy; anak usia kanak-kanak madya.

\begin{abstract}
Middle childhood children have developmental changes in some aspects. These changes turn out to be challenges for the parents to keep implementing positive parenting. In order to have the positive parenting outcomes, parents ought to have certain level of parenting self efficacy. How parents perceived their parent involvement when they're still kids might have impact on how they feel capable in their involvement when they do parenting proces to their children now. What types of parenting strategies they chose might also give impact to their parenting self efficacy. This quantitative study aimed to examine the contribution of perceived parent involvement (as a father and/or a mother to his/her middle childhood child) and parenting strategies to parenting self-efficacy. This study used questionnaires to gather data from participants. Reported Father Involvement Scales (Finley \& Schwartz, 2004) and Reported Mother Involvement Scales (Finley, Mira, \& Schwartz, 2008) have been used to measure perceived parent involvement. Parenting Strategies Questionnaire (Laforce, 2004) also have been used to measure the parenting strategies, while parenting self-efficacy was measured by the modification of Self-Efficacy for Parenting Task Index from Coleman \& Karraker (2000). Total participants in this study were 270 parents (a
\end{abstract}


father and/or a mother, aged 25-45 years) with children in middle childhood (aged 5 - 12 years) consisting of 134 fathers and 136 mothers. Participants obtained by convenience sampling technique. The results indicated that perceived parent involvement and parenting strategies together significantly influenced parenting self-efficacy both in fathers $(F(2,267)$ $=13.805, p<0.01)$ as well as in mothers $(F(2,267)=11.021, p<0.01)$. The implications of this research can be used for parents with middle childhood children and will be discussed in this article.

Keywords: perceived parental involvement, parenting strategies, parenting self-efficacy, middle childhood children.

\section{Pendahuluan}

Dalam proses pengasuhan, orangtua menjadi salah satu kontributor yang sangat penting bagi perkembangan anak. Salah satu kompetensi yang perlu dimiliki orangtua yakni parenting self-efficacy. Coleman dan Karraker (2000) mendefinisikan parenting self-efficacy sebagai estimasi terhadap kompetensi dalam menjalankan peran sebagai orangtua atau persepsi dalam memandang kemampuannya yang dapat memengaruhi perilaku dan perkembangan anak secara positif. Parenting self-efficacy berperan secara signifikan bagi orangtua dalam mempertahankan praktik pengasuhan yang efektif ketika dihadapkan dengan berbagai tantangan yang dapat memengaruhi perkembangan dan perilaku anak (Jones \& Prinz, 2005; Dumka, Gonzales, Wheeler, \& Millsap, 2010).

Menurut Coleman dan Karraker (2000), parenting self-efficacy yang tinggi berhubungan dengan kemampuan orangtua untuk menyediakan lingkungan pengasuhan yang adaptif dan stimulatif, meningkatkan kepekaan orangtua terhadap kebutuhan anak, dan keterikatan dalam interaksi langsung sebagai orangtua. Sebaliknya, parenting self-efficacy yang rendah berdampak pada perilaku pengasuhan (defensive dan controlling behavior), munculnya persepsi orangtua mengenai kesulitan pada anak, tingkat stres yang tinggi pada orangtua, munculnya masalah perilaku pada anak seperti kecemasan, agresif, hiperaktif, dan kekerasan pada teman sebaya
(Coleman \& Karraker, 2000; Secer \& Ogelman, 2012). Berdasarkan penjabaran tersebut terlihat bahwa parenting selfefficacy secara positif berhubungan dengan kualitas pengasuhan dan memengaruhi perkembangan anak.

Beberapa faktor yang memengaruhi parenting self-efficacy diantaranya pengalaman masa kecil orangtua, elemen sosial budaya dan komunitas tempat tinggal, dukungan sosial dan pernikahan (social marital), faktor kesiapan kognitif orangtua, pengalaman dengan anak, dan karakteristik anak (Coleman \& Karraker, 1998). Pada penelitian ini akan lebih memfokuskan pada pengalaman masa kecil orangtua yang akan dilihat dari persepsi keterlibatan orangtuanya di masa lalu dan pengalaman dengan anak yang akan dilihat dari bagaimana orangtua menerapkan strategi pengasuhan pada anak. Hal ini juga ditunjang oleh penelitian yang dilakukan oleh Murdock (2013) yang menemukan bahwa parenting selfefficacy pada ayah dan ibu memiliki keterkaitan dengan afeksi yang dimiliki orangtua (terutama yang positif) dan bagaimana mereka melakukan pengasuhan terhadap anaknya. Lebih lanjut, parenting self-efficacy juga berkembang secara kontinu melalui proses evaluasi kognitif, respon emosi dan perilaku yang diterima oleh anak yang kemudian akan tercermin dari interaksi yang dilakukan orangtua pada anaknya (Sanders \& Mazzucchelli, 2013).

Menurut hasil penelitian Leerkes dan Crockenberg (2002, dalam Coleman 
\& Karraker, 2005) pengalaman masa kecil orangtua memberikan peluang besar munculnya parenting self-efficacy melalui proses vicarious learning. Proses tersebut didasarkan pada identifikasi terhadap role model. Dalam hal ini orangtua dianggap sebagai role model bagi anak untuk menjalani berbagai tugas pengasuhan. Selain itu, Schofield, Conger, dan Neppl (2014) juga menjelaskan orangtua yang percaya dengan perilaku pengasuhan orangtuanya dahulu berdampak pada upaya dalam mengasuh anak mereka. Pada pengalaman masa kecil orangtua dapat dilihat dengan adanya keterlibatan orangtua sebagai pengasuh utama pada diri orangtua sebagai anak.

Persepsi keterlibatan orangtua didefinisikan sebagai sejauh mana orangtua menunjukkan perilaku yang menandakan bahwa mereka ikut berpartisipasi dalam berbagai aspek kehidupan anak (Finley dkk., 2008). Dalam proses pengasuhan anak, keterlibatan antara seorang ayah dan ibu memiliki peran yang berbeda. Pada umumnya ibu dianggap sebagai pengasuh utama karena banyak terlibat dalam aktivitas sehari-hari khususnya peran ekspresif pengasuhan seperti emosi dan pertemanan (Giallo, Treyvaud, Cooklin, \& Wade, 2013), sedangkan ayah lebih dominan pada peran instrumental seperti mencari nafkah, menerapkan sikap disiplin (Finley \& Schwartz, 2006), mengontrol perilaku anak serta memberikan perlindungan (Murdock, 2013).

Menurut Finley dkk. (2008) semakin tinggi persepsi anak (dalam hal ini orangtua) dalam menilai pengalaman keterlibatan orangtuanya, maka akan semakin tinggi pula tingkat keterlibatan orangtuanya dalam kehidupan anak. Dengan kata lain, semakin tinggi orangtua menilai keterlibatan orangtuanya (di masa lalu), maka saat ia (sebagai orangtua pada masa kini) juga akan semakin terlibat dalam kehidupan (pengasuhan) anaknya. Oleh karena itulah, dapat dilihat bahwa keterlibatan orangtua memiliki dampak jangka panjang bagi perkembangan anak, yang tentunya juga akan memengaruhi perilaku pengasuhan anak yang dilakukan dirinya saat ia kelak menjadi orangtua.

Hasil penelitian menunjukkan bahwa persepsi seseorang terhadap keterlibatan orangtuanya di masa lalu ternyata memiliki pengaruh pada parenting selfefficacy yang dimilikinya saat ia sudah beranjak menjadi orangtua (Affiani \& Indrasari, 2017). Hal ini juga didukung oleh penelitian yang dilakukan oleh Juhari, Yaacob, dan Thalib (2013) bahwa persepsi keterlibatan ayah di masa lalu memiliki hubungan dengan parenting selfefficacy ayah saat si anak sudah menjadi orangtua. Selain itu, ketika seseorang memiliki pengalaman masa kecil dengan orangtua yang responsif dan ia menilai puas akan keterlibatan yang dilakukan orangtuanya dalam pengasuhan, maka saat ia telah beranjak menjadi orangtua, ia mampu mengembangkan keyakinan bahwa mereka dapat menjalani hubungan yang kuat dan cenderung mau lebih terlibat terhadap anak-anak mereka (Holloway, Suzuki, Yamamoto, \& Bahrens, 2005).

Tidak hanya pengalaman keterlibatan orangtua yang memengaruhi parenting self-efficacy, perilaku orangtua dalam mengasuh anak secara langsung juga berhubungan dengan parenting selfefficacy (Laforce, 2004). Perilaku tersebut berkaitan dengan strategi pengasuhan yang dilakukan orangtua terhadap anak. Tepat atau tidaknya strategi pengasuhan orangtua terkait dengan bagaimana orangtua memilih cara yang terbaik untuk berinteraksi dengan anak maupun mengasuh anaknya. Orangtua yang menilai dirinya kompeten maka akan lebih terlibat dalam mengupayakan strategi pengasuhan yang dapat meningkatkan kemungkinan anak untuk berhasil pada domain akademis, sosial dan psikologis (Jones \& Prinz, 2005). Sebaliknya jika orangtua tidak memiliki kendali terhadap perilaku buruk anak dan memiliki parenting selfefficacy yang rendah, maka besar kemungkinan orangtua menyimpan pikiran 
dan emosi negatif terhadap perilaku anak dan cara yang tepat untuk menanganinya perilaku mereka (Fass, Khoury-Kassabri \& Koot, 2018).

Strategi pengasuhan merupakan berbagai bentuk tingkah laku orangtua untuk mengarahkan dan memengaruhi perilaku anak (Laforce, 2004). Strategi pengasuhan juga dapat didefinisikan sebagai serangkaian aktivitas yang dilakukan orangtua untuk menjaga anaknya dari pengalaman negatif dengan cara mengembangkan keterampilan anak (Celada, 2010). Laforce (2004) mengelompokkan strategi pengasuhan menjadi tiga domain, yaitu reasoning strategies, engagement/attention strategies, dan power-assertion strategies.

Strategi reasoning diartikan sebagai cara untuk menolong anak menginternalisasikan nilai-nilai yang ada dan mengembangkan moral pribadinya. Strategi ini digunakan orangtua dengan mengembangkan logika anak, mengacu pada norma-norma sosial, perasaan terhadap orang lain, dan konsekuensi alami yang akan diterima oleh anak (Laforce, 2004). Strategi kedua yakni engagement/attention terkait dengan bagaimana peran orangtua mengontrol perilaku bermasalah anak. Engagement/attention strategies ini dinilai cukup berperan dalam proses interaksi antara orangtua dan anak (Laforce, 2004). Selanjutnya, strategi power-assertion merupakan strategi dengan memberikan kontrol satu arah terhadap interaksi, seperti halnya memberikan hak atau mengambilnya, memberikan perintah atau instruksi, dan juga menggunakan hukuman fisik. Ketiga strategi tersebut berfokus pada perilaku orangtua melakukan pengasuhan anaknya (behavior-focused) (Laforce, 2004).

Laforce (2004) menyatakan bahwa orangtua dengan parenting self-efficacy yang rendah berhubungan dengan perilaku pengasuhan yang disfungsional. Contoh nyatanya, low parenting selfefficacy seringkali diasosiasikan dengan abusive parenting, inconsistent discipline dalam pengasuhan, dan corporal pun- ishment (Fass dkk., 2018). Kemudian, Laforce (2004) menyatakan secara teoritis parenting self-efficacy memiliki hubungan dengan bagaimana orangtua memilih untuk bertingkah laku dalam proses pengasuhan. Hasil penelitian menunjukkan bahwa terdapat hubungan positif dan signfikan antara penggunaan strategi pengasuhan dengan parenting self-efficacy (Laforce, 2004; Sumargi, Sofronoff, \& Morawska, 2015; Monica \& Indrasari, 2016), semakin efektif strategi pengasuhan yang diterapkan oleh orangtua terhadap anak, maka semakin tinggi pula tingkat parenting self-efficacy yang dimiliki orangtua tersebut.

Meskipun keyakinan orangtua dalam mengasuh anak dipengaruhi pengalaman keterlibatan orangtua sejak kecil dan tingkah laku pengasuhan, tidak menutup kemungkinan bahwa keyakinan yang orangtua miliki dapat berbeda tergantung masing-masing orangtua mempersepsikan pengalamannya tersebut. Hal tersebut karena parenting self-efficacy sendiri juga dapat berubah seiring dengan perkembangan anak (Jones \& Prinz, 2005). Semakin bertambahnya usia anak maka tuntutan dan tugas pengasuhan yang dilakukan orangtua juga berbeda.

Pada tahap perkembangan usia kanak-kanak madya (middle childhood) misalnya, anak pada tahap ini berada di rentang usia 5-12 tahun (Collins, Madsen, \& Susman-Stillman; Bornstein, 2002) dan mengalami pertumbuhan kognitif untuk mengembangkan konsep yang lebih kompleks mengenai kemampuan regulasi emosi (Movahed Abtahi \& Kerns, 2017). Selain itu, pada tahap ini anak akan lebih banyak menghabiskan waktu di sekolah dan bersosialisasi dengan teman sebaya sehingga adanya perubahan figur attachment (Movahed Abtahi \& Kerns, 2017). Untuk itu tugas pengasuhan anak pada usia kanak-kanak madya banyak yang perlu diperhatikan oleh orangtua, seperti memberikan pengawasan dan pengarahan kepada anak-anak dari jarak tertentu ketika mereka sedang berada di sekolah atau bersama dengan teman-temannya. 
Lebih lanjut, dalam proses mengasuh anak usia kanak-kanak madya, tidak sedikit orangtua mengalami beberapa kecemasan mengenai tanggung jawab dalam mengasuh anak (Papalia \& Feldman, 2012). Masalah yang ditemukan pada usia kanak-kanak madya seperti kecemasan (Demby, Riggs, \& Kaminski, 2017) dan berkelahi yang mungkin dapat menimbulkan perasaan lelah, bersalah, bahkan gagal pada diri orangtua (Altman, 2006). Kondisi ini akan memengaruhi pengasuhan orangtua terhadap perkembangan anak. Oleh karena itu, orangtua diharapkan memiliki kompetensi pengasuhan untuk menghasilkan perkembangan positif pada anak mereka.

Berdasarkan penjabaran di atas, peran keterlibatan orang tua di masa lalu maupun strategi pengasuhan memiliki keterkaitan satu sama lain dengan parenting self-efficacy. Ketika orangtua menilai bahwa kedua orangtuanya banyak terlibat pada tingkah laku pengasuhan yang positif di masa kecil, maka orangtua berpeluang besar untuk melakukan strategi pengasuhan yang positif dan mampu menjalankan peran sebagai orangtua. Untuk itulah penelitian ini bertujuan untuk mengetahui kontribusi persepsi keterlibatan orangtua dan strategi pengasuhan terhadap parenting self-efficacy yang dimiliki oleh orangtua yang memiliki anak berusia kanak-kanak madya.

\section{Metode Penelitian}

Partisipan. Jumlah partisipan pada penelitian ini berjumlah 270 orang, terdiri dari ayah 134 orang dan ibu 136 orang, dengan mean usia $=38.95$ tahun, standar deviasi $=4.271$. Adapun karakteristik partisipan ini adalah orangtua baik ayah maupun ibu (boleh tidak berpasangan) yang tergolong dewasa muda berusia 2545 tahun dan memiliki anak berusia 5-12 tahun (tergolong kanak-kanak madya). Alasan pemilihan partisipan ini didasari pada adanya tuntutan pada orangtua yang terkait dengan tugas pengasuhan yang secara efektif dilakukan seiring dengan adanya perubahan signifkan didalam perkembangan emosi, kognitif, dan psikososial anaknya (Brooks, 2011), dan pada usia dewasa muda individu telah menikah, memiliki anak, dan memiliki pekerjaan yang relatif stabil (Arnett, 2012). Selain itu, tahap perkembangan pada anak usia kanak-kanak madya yakni adanya perubahan figur attachment dan kemandirian dalam meregulasi emosi (Movahed Abtahi \& Kerns, 2017).

Teknik sampling yang digunakan yakni convenience sampling yang berarti mengambil sampel dari individu yang mudah ditemukan selama penelitian dan termasuk dalam karakteristik subjek penelitian (Gravetter \& Forzano, 2012).

Desain. Parenting Self-Efficacy. Penelitian ini menggunakan alat ukur SelfEfficacy for Parenting Task Index (SEPTI) milik Coleman dan Karraker (2000) yang terdiri dari 36 aitem berupa pernyataan yang dibagi menjadi lima dimensi yaitu prestasi, rekreasi, disiplin, nurturance, dan kesehatan. Dimensi prestasi untuk mengukur kompetensi orangtua terkait dengan perkembangan kognitif seperti dukungan prestasi anak di sekolah, dimensi rekreasi untuk mengukur kebutuhan perkembangan sosial anak seperti bersosialisasi dengan teman sebaya, dimensi disiplin yakni mengukur kemampuan untuk menerapkan aturanaturan yang sesuai, dimensi nurturance untuk mengukur kompetensi orangtua mencakup kebutuhan anak dan kehangatan secara emosional, serta dimensi kesehatan untuk mengukur kompetensi orangtua mencakup penyediaan nutrisi dan perawatan kesehatan yang tepat.

Skala yang digunakan pada alat ukur ini berupa skala Likert yang terdiri dari 6 skala, dimulai dari 1 (Sangat Tidak Sesuai) hingga 6 (Sangat Sesuai). Perhitungan uji reliabilitas alat ukur dalam penelitian ini dilakukan kepada 120 orangtua dengan anak usia kanak-kanak madya yang terdiri dari 60 orang ayah dan 60 orang ibu. Berdasarkan hasil uji coba didapatkan nilai Cronbach Alpha sebesar $\alpha=0,889$. Hal ini menunjukkan bahwa secara keseluruhan alat ukur 
SEPTI tergolong reliabel.

Perceived Parental Involvement. Untuk mengukur variabel persepsi keterlibatan orangtua, peneliti menggunakan alat ukur persepsi keterlibatan ayah yakni Reported Father Involvement Scales (RFIS) yang disusun oleh Finley dan Schwartz (2004), sedangkan alat ukur persepsi keterlibatan ibu yaitu Reported Mother Involvement Scales (RMIS) yang dikembangkan kembali oleh Finley dkk., (2008). Masing-masing alat ukur tersebut terdiri dari 20 aitem yang menggambarkan 20 aspek perkembangan pada anak dan terdiri dari tiga dimensi yaitu instrumental, ekspresif, dan mentoring/advising. Peneliti menggunakan alat yang sudah diadaptasi dan diterjemahkan oleh Ayu (2014) mengenai persepsi keterlibatan ayah, kemudian peneliti menggunakan alat ukur yang sama dengan keterlibatan ayah dengan mengganti figur ayah menjadi ibu sesuai dengan teori dan alat ukur yang dikembangkan Finley dkk. (2008). Aitem pada alat ukur ini berupa pernyataan. Skala yang digunakan pada alat ukur ini berupa skala Likert yang terdiri dari 5 skala, dimulai dari 1 (tidak pernah terlibat), 2 (jarang terlibat), 3 (kadang-kadang terlibat), 4 (sering terlibat), dan 5 (selalu terlibat).

Uji reliabilitas alat ukur RFIS dan RMIS dilakukan kepada 60 orangtua dengan anak usia kanak-kanak madya yang terdiri dari 30 orang ayah dan 30 orang ibu (boleh tidak berpasangan). Berdasarkan hasil uji coba alat ukur RFIS didapatkan nilai koefisien reliabilitas sebesar $\alpha=0,953$, sedangkan alat ukur RMIS sebesar $\alpha=0,912$. Nilai reliabilitas sebesar 0,9 pada alat ukur bukan berarti memiliki social desirability yang tinggi melainkan konsisten dalam mengukur apa yang hendak diukur (Kaplan \& Saccuzo, 2005). Dengan demikian, dapat dikatakan bahwa alat ukur RFIS dan RMIS memiliki internal konsistensi yang baik, aitemaitem pada alat ukur tersebut secara konsisten mengukur konstruk keterlibatan orangtua.
Parenting Strategy. Pengukuran variabel strategi pengasuhan menggunakan alat ukur Parenting Strategies Questionnaire (PSQ) milik Laforce (2004) yang terdiri dari ketiga dimensi parenting strategies, yaitu: reasoning, engagement, dan power-assertion. PSQ terdiri dari 59 item yang berfokus pada perilaku pengasuhan yang dilakukan oleh orangtua terhadap satu orang anaknya, dan dilihat berdasarkan perilaku pengasuhan selama satu bulan terakhir. Pengukuran terhadap strategi pengasuhan dilihat berdasarkan 6 skala Likert yang mengukur frekuensi, mulai dari "Tidak Pernah", "Jarang", "Kadang-kadang", "Sering", "Sangat Sering", dan "Selalu".

Pengukuran ini menekankan pada frekuensi penggunaan strategi dalam tingkah laku pengasuhan dengan menggunakan skala rating, dan bukan menekankan pada digunakan atau tidaknya suatu strategi. Pertimbangan tersebut karena orangtua cenderung menggunakan strategi yang bervariasi, dan konteks interaksi antara orangtua dengan anak cenderung lebih memengaruhi pemilihan strategi dibandingkan dengan karakteristik kepribadian personal orangtua (Laforce, 2004). Uji reliabilitas alat ukur PSQ dilakukan kepada 60 orangtua (30 ayah dan $30 \mathrm{ibu}$ ) dengan anak usia kanakkanak madya diperolah hasil bahwa secara keseluruhan alat ukur PSQ yang telah diadaptasi ke dalam Bahasa Indonesia memiliki nilai reliabilitas Cronbach Alpha sebesar $\alpha=0,945$.

Prosedur. Peneliti menyebarkan kuesioner tertulis kepada partisipan baik secara langsung kepada orangtua maupun melalui sekolah (TK dan SD) untuk disampaikan kepada orangtua. Melalui sekolah, peneliti sebelumnya meminta izin kepada pihak sekolah dengan memberikan surat izin pengambilan data. Setelah mendapatkan izin, peneliti memberikan kuesioner kepada wali kelas untuk dititipkan kepada anak murid yang memiliki orangtua dengan rentang usia 25-45 tahun. Orangtua murid berhak untuk tidak bersedia dalam penelitian ini 
Tabel 1. Statistik deskriptif dan korelasi antar variabel

\begin{tabular}{|c|c|c|c|c|c|c|c|}
\hline & M & $S D$ & N & 1 & 2 & 3 & 4 \\
\hline 1. Parenting Self-Efficacy & 167,36 & 15,452 & 270 & - & $0,245^{\star *}$ & - & $0,241^{* *}$ \\
\hline $\begin{array}{l}\text { 2. Persepsi keterlibatan } \\
\text { Ayah }\end{array}$ & 71,57 & 14,212 & 270 & $0,245^{\star *}$ & - & - & $0,260^{* *}$ \\
\hline 3. Persepsi keterlibatan Ibu & 78,60 & 12,325 & 270 & $0,204^{* *}$ & - & - & $0,313^{* *}$ \\
\hline 4. Strategi Pengasuhan & 221,21 & 32,122 & 270 & $0,241^{* *}$ & $0,260^{* *}$ & $0,313^{* *}$ & - \\
\hline
\end{tabular}

Keterangan: ${ }^{*} p<0,05,{ }^{* *} p<0,01$, (one-tailed)

dan mengembalikan kuesioner kepada peneliti. Peneliti memberikan waktu selama dua hari untuk mengisi kuesioner tersebut. Setelah itu, peneliti mendatangi pihak sekolah untuk mengumpulkan kuesioner yang sudah terisi dan memberikan souvenir sebagai tanda terima kasih karena sudah berkenan menjadi partisipan dalam penelitian ini.

Teknik Analisis. Setelah data didapatkan, peneliti menyeleksi berdasarkan kelengkapan pengisian dan data demografis partisipan. Setelah mendapat kuesioner yang terisi lengkap, peneliti melakukan input data dan penyekoran dari tiap kuesioner. Pengolahan data diawali dengan menggunakan program Microsoft Excel 2010, kemudian untuk analisis statistik lebih lanjut menggunakan program IBM SPSS Statistics 23.0. Setelah seluruh data terkumpul, peneliti menggunakan beberapa teknik perhitungan, yakni perhitungan statistika deskriptif untuk mengetahui gambaran umum karakteristik partisipan berdasarkan aspek demografi seperti jenis kelamin orangtua, suku bangsa, tingkat pendidikan akhir, dan pekerjaan. Kemudian teknik multiple regression untuk menganalisis pengaruh antara persepsi keterlibatan orangtua dan strategi pengasuhan terhadap parenting self-efficacy.

\section{Hasil Penelitian}

Berdasarkan data demografis diketahui gambaran data partisipan pene- litian, Partisipan terdiri dari ibu dan ayah dengan jumlah ayah sebanyak 134 $(49,6 \%)$ dan 136 ibu $(50,4 \%)$. Kemudian dari suku bangsa, mayoritas partisipan bersuku Jawa yakni berjumlah 94 orang $(34,8 \%)$, diikuti suku Betawi berjumlah 51 orang $(18,9 \%)$, dan sisa suku lainnya dengan persentase $46,3 \%$. Dari segi tingkat pendidikan akhir mayoritas partisipan memiliki pendidikan SMA yakni berjumlah 121 orang $(44,8 \%)$, lalu pendidikan S1 berjumlah 90 orang $(33,3 \%)$, dan sisa pendidikan lainnya $21,9 \%$. Dari segi pekerjaan mayoritas partisipan bekerja sebagai pegawai swasta berjumlah 99 orang $(36,7 \%)$, diikuti pekerjaan sebagai ibu rumah tangga sebanyak 77 orang $(28,5 \%)$, dan pekerjaan lainnya sebesar $34,8 \%$. Tabel 1 adalah deskriptif variabel.

Selanjutnya untuk menganalisis pengaruh antara persepsi keterlibatan orangtua (ayah dan ibu) dan parenting strategy terhadap parenting self-efficacy dilakukan uji statistik multiple regression. Perhitungan akan dibagi menjadi dua yaitu berdasarkan persepsi keterlibatan ayah dan strategi pengasuhan terhadap parenting self-efficacy, kemudian persepsi keterlibatan ibu dan strategi pengasuhan terhadap parenting self-efficacy.

Berdasarkan perhitungan, ditemukan hasil bahwa persepsi keterlibatan ayah dan strategi pengasuhan memiliki pengaruh yang signifikan secara bersama-sama terhadap parenting selfefficacy, $F(2,267)=13.805, \quad p<0.01$. 
Tabel 2. Hasil Analisis Multiple Regression Persepsi Keterlibatan Ayah, Strategi Pengasuhan, dan Parenting Self-Efficacy

\begin{tabular}{ccccc}
\hline \multirow{2}{*}{ Variabel } & \multicolumn{4}{c}{ Parenting Self-Efficacy } \\
\cline { 2 - 5 } & $\mathrm{R}^{2}$ & $\mathrm{~F}$ & Sig. & $\beta$ \\
\hline $\begin{array}{c}\text { Persepsi keterlibatan ayah } \\
\text { Strategi Pengasuhan }\end{array}$ & 0,094 & 13,805 & $0,000^{* *}$ & 0,196 \\
& & & & 0,190 \\
\hline
\end{tabular}

Keterangan:

Dependent Variable: Parenting Self-Efficacy

Preediktor: (Konstan), Persepsi keterlibatan ayah dan Strategi Pengasuhan

${ }^{*} p<0,05 .{ }^{* *} p<0,01$, (one-tailed).

\section{Tabel 3. Hasil Analisis Multiple Regression Persepsi Keterlibatan Ibu, Strategi Pengasuhan, dan Parenting Self-Efficacy}

\begin{tabular}{ccccc}
\hline \multirow{2}{*}{ Variabel } & \multicolumn{4}{c}{ Parenting Self-Efficacy } \\
\cline { 2 - 5 } & $R^{2}$ & $F$ & Sig. & $\beta$ \\
\hline Persepsi keterlibatan Ibu & 0,076 & 11,021 & $0,000^{* *}$ & 0,142 \\
Strategi Pengasuhan & & & & 0,196 \\
\hline
\end{tabular}

Keterangan:

Dependent Variable: Parenting Self-Efficacy

Prediktor: (Konstan), Persepsi keterlibatan Ibu dan Strategi Pengasuhan ${ }^{*} p<0,05 .{ }^{* *} p<0,01$, (one-tailed).

Hasil tersebut menunjukkan adanya kontribusi persepsi keterlibatan ayah dan strategi pengasuhan yang signifikan secara bersama-sama terhadap parenting self-efficacy pada orangtua yang memiliki anak berusia kanak-kanak madya. Diketahui bahwa coefficient of determination $\left(\mathrm{R}^{2}\right)$ yang diperoleh dari perhitungan antara persepsi keterlibatan ayah dan strategi pengasuhan sebesar 0.094 (lihat tabel 2). Hal itu berarti bahwa sebesar $9,4 \%$ varians parenting selfefficacy dapat diprediksi oleh persepsi keterlibatan ayah dan strategi pengasuhan dan $90.6 \%$ sisanya diprediksi oleh faktor lain. Dengan $\mathrm{R}^{2}=0.094$ pengaruh persepsi keterlibatan ayah dan strategi pengasuhan terhadap parenting selfefficacy tergolong lemah (Gravetter \& Wallnau, 2013).
Selanjutnya ditemukan hasil bahwa persepsi keterlibatan ibu dan strategi pengasuhan memiliki pengaruh yang signifikan secara bersama-sama terhadap parenting self-efficacy, $\mathrm{F}(2,267)=$ 11.021, $p<0.01$. Hasil tersebut ditemukan adanya pengaruh antara persepsi keterlibatan ibu dan strategi pengasuhan yang signifikan secara bersama-sama terhadap parenting self-efficacy pada orangtua yang memiliki anak berusia kanak-kanak madya. Diperoleh coefficient of determination $\mathrm{R}^{2}=0.076$ yang berarti, $7,6 \%$ varians parenting self-efficacy dapat diprediksi oleh persepsi keterlibatan ibu dan strategi pengasuhan dan $92.4 \%$ sisanya diprediksi oleh faktor lain (lihat tabel 3 ). Dengan $R^{2}=0.076$ pengaruh persepsi keterlibatan ibu dan strategi pengasuhan terhadap parenting self-efficacy tergolong lemah (Gravetter \& Wallnau, 2013). 


\section{Diskusi}

Penelitian ini bertujuan untuk mengetahui pengaruh persepsi keterlibatan orangtua dan strategi pengasuhan terhadap parenting self-efficacy. Secara spesifik, persepsi keterlibatan orangtua dilihat dari keterlibatan ayah dan keterlibatan ibu. Hasil menunjukkan bahwa terdapat kontribusi antara persepsi keterlibatan orangtua dan strategi pengasuhan yang signifikan secara bersama-sama terhadap parenting self-efficacy pada orangtua dengan anak usia kanak-kanak madya. Hal tersebut berarti parenting self-efficacy dapat diprediksi oleh persepsi keterlibatan orangtua di masa lalu dan strategi pengasuhan. Hasil ini sejalan dengan penelitian sebelumnya bahwa terdapat hubungan antara keterlibatan orangtua dengan parenting self-efficacy (Juhari dkk., 2013; Holloway dkk., 2015). Ketika orangtua memiliki pengalaman masa kecil dengan orangtua yang responsif dan dapat dipercaya, maka orangtua akan mengembangkan keyakinan bahwa mereka mampu menjalani hubungan yang kuat dan memuaskan anakanak mereka. Temuan ini juga diperkuat penelitian Murdock (2013) yang menyebutkan bahwa keyakinan yang dimiliki oleh orangtua (Parenting Self-Efficacy) dipengaruhi oleh perilaku pengasuhan (positif maupun negatif) yang dilakukan orangtua terhadap anaknya. Hal ini juga termasuk didalamnya adalah seberapa yakin orangtua dalam menilai kompetensi dirinya dalam melakukan pengasuhan terhadap anaknya.

Hasil penelitian ini juga mendukung hasil penelitian yang menyatakan adanya hubungan antara strategi pengasuhan dan parenting self-efficacy (Laforce, 2004; Celada, 2010; Monica \& Indrasari, 2016). Dengan tingkat keyakinan yang dimiliki orangtua dalam melakukan pengasuhan anak, orangtua juga melakukan serangkaian kegiatan yang bertujuan untuk "menjaga" anaknya dari pengalaman negatif dengan cara mengembangkan keterampilan anak (Celada, 2010). Hubungan antara strategi pengasuhan dan parenting self-efficacy dapat terjadi karena baik strategi pengasuhan maupun parenting self-efficacy berfokus pada tingkah laku dan performa orangtua dalam pengasuhan. Hal tersebut diperkuat Laforce (2004) yang menyebutkan bahwa strategi pengasuhan dengan ketiga domain di dalamnya (reasoning strategies, engagement/attention strategies, dan power-assertion strategies) merupakan suatu konstruk yang behavior-focused dan mengukur tingkat strategi pengasuhan berdasarkan frekuensi munculnya tingkah laku pengasuhan tertentu yang dilakukan orangtua. Ketika orangtua mengestimasi kemampuannya dalam pengasuhan, orangtua sekaligus mengevaluasi performa dari tingkah laku pengasuhan yang dilakukan, yakni apakah tingkah lakunya tersebut efektif dan membawa pengaruh positif bagi anak.

Melihat gambaran parenting selfefficacy mayoritas orangtua pada pada penelitian ini memiliki parenting selfefficacy yang tinggi. Hasil ini mendukung penelitian Sumargi dkk. (2015) bahwa orangtua Indonesia memiliki parenting self-efficacy yang tinggi dan tingkat stres pengasuhan yang rendah sehingga mereka mampu menangani masalah perilaku pada anak secara efektif dan konsisten. Tidak hanya itu, baik parenting self-efficacy ayah dan parenting selfefficacy ibu ditemukan hasil yang tidak jauh berbeda. Dengan begitu terlihat bawah figur ayah kini banyak terlibat dalam pengasuhan dan memiliki keyakinan yang sama-sama tergolong tinggi dengan ibu. Hal ini menjadi penting dalam praktik pengasuhan di masa kini bahwa ayah dan ibu memiliki peran pengasuhan yang seimbang, bukan hanya ibu yang bertanggung jawab dalam pengasuhan. Dengan semakin terlibatnya peran ayah dalam pengasuhan dapat memberikan pengaruh positif bagi anak (sedikitnya masalah perilaku dan kemampuan regulasi diri yang lebih baik) melalui coparenting (Cabrera, Volling, \& Barr, 2018). Selain itu, ayah dan ibu dapat bekerja sama untuk menerapkan peng- 
asuhan yang lebih efektif dengan memberikan dukungan satu sama lain sehingga dapat meningkatkan parenting self-effiicacy (Merrifield \& Gamble, 2013).

\section{Kesimpulan}

Hasil penelitian ini menunjukkan bahwa persepsi keterlibatan orangtua dan strategi pengasuhan memiliki pengaruh yang signifikan terhadap parenting self-efficacy pada orangtua, namun kekuatan pengaruh antara keduanya tergolong lemah. Lemahnya pengaruh diasumsikan karena persepsi keterlibatan orangtua dan strategi pengasuhan merupakan konsep yang masih sangat luas yang dipengaruhi oleh beragam faktor. Laforce (2004) menyebutkan bahwa skala pengukuran terhadap strategi pengasuhan memiliki konsistensi internal yang tinggi, namun merefleksikan konsep yang sangat meluas. Oleh karena itu, memang sangat mungkin respon partisipan terhadap pernyataan pada aitem-aitem strategi pengasuhan sangat dipengaruhi berbagai faktor, diikuti pula dengan beragamnya karakteristik partisipan. Faktor budaya juga diasumsikan menjadi hal yang penting karena dalam mengasuh anak di Indonesia yang memiliki keberagaman suku bangsa, tentu akan mempengaruhi bagaimana orangtua mengadaptasi dan menerapkan nilai-nilai dan perilaku pengasuhannya berdasarkan ras, etnisitas, dan status sosialnya.

Pada penelitian ini masih terdapat keterbatasan yang ditemui selama berlangsungnya penelitian, pada saat pengambilan data kepada partisipan yang dititipkan kuesioner tidak sedikit peneliti mendapatkan kuesioner yang tidak terisi lengkap baik pada aitem dan data demografis. Kemudian, nilai koefisien reliabilitas yang dihasilkan dari masingmasing alat ukur tergolong tinggi. Untuk itu perlu ditinjau kembali mengenai aitemaitem pada alat ukur tersebut yang disesuaikan dengan konteks keberagaman budaya di Indonesia. Penelitian selanjutnya diharapkan dapat menerapkan metode pengambilan data pada par- tisipan ayah dan ibu (pada pasangan suami istri yang sama) sehingga hasil yang diperoleh dapat menjadi lebih objektif dan mengurangi bias yang muncul akibat penilaian diri (self-report). Selanjutnya, hasil penilaian yang diperoleh dari penilaian diri sendiri dicocokkan/diselaraskan dengan penilaian yang diperoleh dari pasangan masing-masing. Dengan demikian hasil yang diperoleh juga bisa lebih akurat untuk memprediksi parenting self-efficacy yang dimiliki oleh ayah dan ibu.

\section{Daftar Pustaka}

Affiani, L., \& Indrasari, S.Y. (2017). The Influence of perceived parental involvement on parenting self-efficacy among parents with middlechildhood children. UI Proceedings on Social Science and Humanities, 1. Retrieved from http://proceedings.ui.ac.id/index.php/uipssh/article/view/54

Altman, M. D. (2006). Vicarious experience and the development of parenting self-efficacy (Order No. 3194533). Available from ProQuest Dissertations \& Theses Global. (304916828). Retrieved from https:// remote-lib.ui.ac.id:2155/docview/304916828 ? accountid $=17242$

Arnett, J.J. (2012). New horizons in research on emerging and young adulthood. In Early adulthood in a family context (pp.231-244). Springer New York.

Bornstein, M. H. (2002). Handbook of parenting, volume 1 child and parenting, second edition. London: Lawrence Erlbaum Associates Publishers.

Brooks, J. (2011). The Process of Parenting. $8^{\text {th }}$ ed. Boston: McGraw Hill. future applications. Developmental Review 18(1), 47-85. doi: 10.1006/drev.1997.0448

Cabrera, N. J., Volling, B. L., \& Barr, R. (2018). Fathers are parents, too! widening the lens on parenting for children's development. Child Deve 
lopment Perspectives, 12(3), 152157. doi: 10.1111/cdep.12275.

Celada, T. C. (2010). Parenting styles as related to parental self-efficacy and years living in the united states among latino immigrant mothers (Order No. 3421132). Available from ProQuest Dissertations \& Theses Global. (750856347).

Coleman, P. K., \& Karraker, K. H. (1998). Self-efficacy and parenting quality: Findings and future applications. Developmental review, 18(1), 47-85. doi: 10.1006/drev.1997.0448.

Coleman, P. K., \& Karraker, K. H. (2000). Parenting self-efficacy among mothers of school-age children: conceptualization, measurement, and correlates. Family Relations,49(1), 13-24. doi: 10.1111/j.1741-3729.2000.00013.x.

Coleman, P.K., \& Karraker, K.H. (2005). Parenting self-efficacy, competence in parenting, and posible links to young children's social and academic outcomes. Dalam O.N. Saracho \& B. Spedek (Eds.). Contemporary perspective on families, communities, and schools for young children.

Collins, W.A., Madsen, S.D., \& SusmanStillman, A. (2002). Parenting during middle childhood. Dalam $\mathrm{M}$. $\mathrm{H}$. Bornstein (Ed.), Handbook of parenting: Children and parenting Vol.1 (2nd ed., pp. 73-1-1). New Jersey: Lawrence Erlbaum Associates, Inc.

Demby, K. P., Riggs, S. A., \& Kaminski, P. L. (2017). Attachment and family processes in children's psychological adjustment in middle childhood. Family process, 56(1), 234249. doi: 10.1111/famp.12145.

Dumka, L. E., Gonzales, N. A., Wheeler, L. A., \& Millsap, R. E. (2010). Parenting self-efficacy and parenting practices over time in mexican american families. Journal of Family Psychology, 24(5), 522531. doi: 10.1037/a0020833
Fass, M. N., Khoury-Kassabri, M., \& Koot, H. M. (2018). Associations between arab mothers' self-efficacy and parenting attitudes and their children's externalizing and internalizing behaviors: Gender differences and the mediating role of corporal punishment. Child Indicators $\mathrm{Re}$ search, 11(4), 1369-1387. doi: 10.1007/s12187-017-9480-9.

Finley, G. E., \& Schwartz, S. J. (2004). The father involvement and nurturant fathering scales: Retrospective measures for adolescent and adult children. Educational and Psychological Measurement, 64(1), 143-164. doi: $10.1177 / 0013164403258453$.

Finley, G. E., \& Schwartz, S. J. (2006). Parsons and Bales revisited: Young adult children's characterization of the fathering role. Psychology of Men \& Masculinity, 7(1), 42-55. doi: 10.1037/1524-9220.7.1.42.

Finley, G.E., Mira, S.D., Schwartz, S.J. (2008). Perceived paternal and maternal involvement: Factor structures, mean differences, and parental roles. Fathering, 6(1), 62-68. doi: 10.3149/fth.0601.62

Giallo, R., Treyvaud, K., Cooklin, A., \& Wade, C. (2013). Mothers' and fathers' involvement in home activities with their children: Psychosocial factors and the role of parental selfefficacy. Early Child Development and Care, 183(3-4), 343-359. doi: 10.1080/03004430.2012.711587.

Gravetter, F.J., \& Forzano, L.B. (2012). Research methods for the behavioural sciences 4th ed. Canada: Wadsworth Cengage Learning.

Gravetter, F.J., \& Wallnou, L.B. (2013). Statistics for the behavioural sciences 9th ed. Canada: Wadsworth Cengage Learning.

Holloway, S. D., Suzuki, S., Yamamoto, Y., \& Behrens, K. Y. (2005). Parenting self-efficacy among Japanese mothers. Journal of comparative family studies, 36(1), 61-76. Retrieved from https://www.jstor.org/stable/41603980 
Jones, T.L., \& Prinz, R.J. (2005). Potential roles of parental selfefficacy in parent and child adjustment: A review. Clinical pyschological review, 25(3). 341-363. doi: 10.1016/j.cpr.2004.12.004.

Jones, T. (2006). Examining potential determinants of parental self-efficacy (Order No. 3232514). Available from ProQuest Dissertations \& amp. Theses Global. (305281405). Retrieved from http://search.proquest.com/docview/305281405?accountid $=17242$

Juhari, R., Yaacob, S. N., \& Talib, M. A. (2013). Father involvement among Malay muslims in Malaysia. Journal of Family Issues, 34(2), 208-227. doi: $10.1177 / 0192513 \times 12461339$.

Kaplan, R. M. \& Saccuzo, D.P. (2005). Psychological testing: Principles, applications, and issues (6th edition). Belmont: Thomson Wadsworth.

Laforce, J. C. (2004). Experience of parenting: Parenting strategies and their relationship with parental selfefficacy, perceptions of control, and parental affect (Order No. NQ99989). Available from ProQuest Dissertations \& Theses Global. (305091375). Retrieved from http:// search.proquest.com/docview/3050 91375? accountid $=17242$

Merrifield, K. A., \& Gamble, W. C. (2013). Associations among marital qualities, supportive and undermining coparenting, and parenting self-efficacy: Testing spillover and stressbuffering processes. Journal of Family Issues, 34(4), 510-533. doi: 10.1177/0192513x12445561.

Monica, J., \& Indrasari, S.Y. (2016). Relationship between parenting strategies and parenting self-efficacy in parents with child at middle child- hood age. Skripsi. Universitas Indonesia.

Movahed Abtahi, M., \& Kerns, K. A. (2017). Attachment and emotion regulation in middle childhood: changes in affect and vagal tone during a social stress task. Attachment \& human development, 19(3), 221-242. doi: 10.1080/14616734.2017.1291696.

Murdock, K. W. (2013). An examination of parental self-efficacy among mothers and fathers. Psychology of Men \& Masculinity, 14(3), 314-323. doi: $10.1037 / \mathrm{a} 0027009$.

Papalia, D.E., \& Feldman, R.D. (2012). Experience human development 12th ed. New York: McGraw-Hill.

Sanders, M. R., \& Mazzucchelli, T. G. (2013). The promotion of self-regulation through parenting interventions. Clinical child and family psychology review, 16(1), 1-17. doi: 10.1007/s10567-013-0129-z.

Secer, Z., \& Ogelman, G. (2012). Analysing mothers' self-efficacy perception towards parenting in relation to peer relationships of 5-6 year-old preschool children. Educational Sciences: Theory and Practice, 12(3), 20012008.

Schofield, T. J., Conger, R. D., \& Neppl, T. K. (2014). Positive parenting, beliefs about parental efficacy, and active coping: Three sources of intergenerational resilience. Journal of Family Psychology, 28(6), 973978. doi: $10.1037 /$ fam0000024.

Sumargi, A., Sofronoff, K., \& Morawska, A. (2015). Understanding parenting practices and parents' views of parenting programs: A survey among Indonesian parents residing in Indonesia and Australia. Journal of Child and Family Studies, 24(1), 141-160. doi: 10.1007/s10826-0139821-3. 